\title{
Novos caminhos para a vida consagrada na realidade Pan-Amazônica
}

New paths for consecrated life in the Pan-Amazonian reality

Ivan Lopes do Nascimento ${ }^{1}$

\section{A realidade pan-amazônica}

A realidade pan-amazônica, retratada no Instrumentum Laboris para o Sínodo Amazônico, tem desafios e possíveis caminhos para a evangelização. Esse documento consta de três partes: a primeira apresenta a realidade territorial pan-amazônica e a de seus povos; a segunda, os desafios ecológicos e pastorais e, a terceira parte, os desafios eclesiológicos e pastorais ${ }^{2}$.

Intitulada "A voz da Amazônia", a primeira parte ressalta a territorialidade pan-amazônica que abarca parte do Brasil, da Bolívia, do Peru, do Equador, da Colômbia, da Venezuela, da Guiana, do Suriname e da Guiana Francesa, em uma extensão de 7,8 milhões de

\footnotetext{
${ }^{1}$ Estudante de Mestrado em Direito Canônico pelo Instituto Superior de Direito Canônico Santa Catarina (Florianópolis - Brasil), bacharel em teologia e mestre em filosofia pelo Ateneo Pontificio Regina Apostolorum (Roma).

2 SECRETARIA GERAL DO SínOdO DOS BISPOS. Instrumentum Laboris para a assembleia especial do Sínodo dos Bispos para a Região Pan-Amazônica sobre o tema Amazônia, novos caminhos para a Igreja e para a ecologia integral. Disponível em: http://www.synod.va/content/sinodoamazonico/pt/documentos/instrumentum-laboris-dosinodo-amazonico.html. Acesso em: 28 jul. 2020.
} 
quilômetros quadrados, no coração da América do Sul. Como se constata, há o desafio da comunicação, dadas as muitas etnias, vários idiomas e dialetos, além do desafio de ser um território extenso e de fronteiras internacionais, cuja logística para o deslocamento de um lugar a outro acarreta custos elevados ${ }^{3}$.

Na segunda parte, "Ecologia integral: o clamor da terra e dos pobres", o documento expõe as fragilidades da Amazônia, tais como: a sua preservação e utilização sustentável dos seus recursos; a marginalização das populações que ali vivem e a migração pendular (vão e vêm), o deslocamento forçado, dentro do mesmo país e para o exterior, a migração voluntária de áreas rurais para as cidades e a migração internacional, com consequências sociais e pastorais inevitáveis ${ }^{4}$.

Finalmente, a terceira parte, "Igreja profética na Amazônia: desafios e esperanças", abarca a inculturação para que as Igrejas locais tenham um rosto amazônico, a conversão pastoral e missionária, no marco de uma clara heterogeneização cultural ${ }^{5}$. Nesse ponto, a vida consagrada, como parte integrante da vida diocesana, não sendo nem clerical nem laical, poderá oferecer uma contribuição preciosa para a evangelização naquele território ${ }^{6}$.

Nesse sentido, o retrato amazônico no Instrumentum Laboris incidirá nas reflexões do Sínodo Especial para a Amazônia, na Exortação Apostólica Pós-Sinodal "Querida Amazônia", na criação da Conferência Eclesial da Amazônia e no estímulo para que a vida consagrada, nas suas mais variadas formas, possa inserir-se de modo profícuo naquela realidade.

\section{A Conferência Eclesial da Amazônia}

Em 29 de junho de 2020, foi criada a Conferência Eclesial da Amazônia como organismo permanente, dando resposta aos apelos do

${ }^{3}$ Ibid., n. 6-43.

${ }^{4}$ Ibid., n. 44-104.

${ }^{5}$ Ibid., n. 105-146.

6 IoAnnes Paulus II, Codex Iuris Canonici, Constitutio Apostolica: Sacra disciplina lege, 1983. In: AAS LXXV Pars II, 1983, 1-327, cânon $588 \S 1$. 
Papa Francisco na sua "Querida Amazônia"; uma vez legitimamente erigida gozará ipso iure de personalidade jurídica?.

Essa conferência eclesial certamente privilegiará o exercício de certas funções pastorais dos bispos daquela região em favor dos fiéis, para o bem da Igreja e para a promoção de novas formas pastorais adaptadas às circunstâncias de tempo e de lugar e, à consecução da sua finalidade, sintetizada nos quatro sonhos ou dimensões propostos pelo Sumo Pontífice: social, cultural, ecológico e eclesial ${ }^{8}$.

Esse órgão eclesial ainda não foi erigido canonicamente pelo Santo Padre, a quem compete exclusivamente essa função, porque difere essencialmente de uma conferência dos bispos, de acordo com o direito universal; provavelmente, será a primeira conferência para uma determinada região que inclui bispos, presbíteros e leigos ${ }^{9}$. Foi eleito, como primeiro presidente da Conferência Eclesial, S. Em. ${ }^{a}$ Revma. Card. Claudio Hummes, sendo também constituído um comitê executivo.

\section{Novos caminhos para a vida consagrada}

Em que sentido o n. 95 da exortação apostólica oferece novos caminhos para vida consagrada dentro da realidade pan-amazônica apresentada no Instrumentum Laboris, que serviu de base para as inúmeras reflexões?

O primeiro caminho é a consciência da importância dos institutos de vida consagrada e das sociedades de vida apostólica que, ainda que não integrem a estrutura hierárquica da Igreja, fazem parte da sua vida e da sua santidade $^{10}$. A vida religiosa, se bem estimulada, poderá inculturar-se e auxiliar a atividade missionária no território pan-amazônico, além de suscitar novas formas de vida religiosa; nesse sentido, a Conferência

\footnotetext{
${ }^{7}$ CIC-1983, cânon 449 §2.

8 Ibid., cânon 447. FRANCISCO. Exortação apostólica pós-sinodal "Querida Amazônia". Disponível em: http:/www.vatican.va/content/francesco/pt/apost_exhortations/documents/ papa-francesco_esortazione-ap_20200202_querida-amazonia.html. Acesso em: 28 jul. 2020. ${ }^{9}$ Ibid., cânones 447, 448, 449 §1 e 451.

${ }^{10}$ Concilium Oecumenicum Vaticanum II, Constitutio Dogmatica de Ecclesiae: Lumen gentium. In: AAS, LVII, 1965, 5-71, n. 39-47. CIC-1983, cânon 577.
} 
Eclesial da Amazônia deverá acompanhar as fundações de novos institutos suscitados como dom do Espírito Santo à Igreja na Amazônia ${ }^{11}$.

Outro caminho importante é o da pastoral vocacional, pois a vida consagrada é parte integrante da vida diocesana e local. O decreto conciliar Perfectae caritatis trata especificamente dos institutos de vida consagrada e ressalta, de modo claro, a importância de um trabalho vocacional com qualidade, em função das necessidades da Igreja, em comunhão com a Igreja diocesana e com o próprio exemplo de vida ${ }^{12}$.

Não menos importante é o caminho da formação específica e permanente dos membros dos institutos que realizam sua missão naquela realidade, possibilitando centros de estudos com excelência acadêmica e reconhecimento canônico e civil ${ }^{13}$. Unida à formação, há o caminho que se encontra indicada na Perfectae caritatis, para que os institutos conservem suas obras, de acordo com as necessidades da Igreja, mas que também saibam adaptá-las às necessidades de tempo e de lugar, imperativo dentro do contexto pan-amazônico ${ }^{14}$.

Por fim, o território é vasto e diversificado cultural e socialmente; por isso, à luz da criação da Conferência Eclesial da Amazônia, um quinto caminho para melhor inserção e promoção da vida consagrada poderia ser a criação de uma conferência para os religiosos naquele território. ${ }^{15}$ Esse organismo daria a sustentação para todos os caminhos anteriormente citados e, em cooperação com a Conferência Eclesial, coordenaria e integraria os trabalhos pastorais, respeitando a autonomia, a índole e o espírito próprio de cada instituto ${ }^{16}$.

\footnotetext{
${ }^{11}$ CONCILIUM OECUMENICUM VATICANUM II, Decretum: Ad gentes. In: AAS, LVIII, 1966, 947-990, n. 18. CONCILIUM OECUMENICUM VATICANUM II, Decretum: Perfectae caritatis. In: AAS, LVIII, 1966, 702-712, n. 19. D. GERALDO, As formas de vida consagrada como dom do espírito santo à Igreja. In: REVISTA DECULTURA TEOLÓGICA, XIX, 2011, 87-109. CIC-1983, cânon 576.

${ }^{12}$ Decret. Perfectae caritatis, n. 24. CIC-1983, cânon 642.

${ }^{13}$ Ibid., n. 18. CIC-1983, cânones 659-661.

${ }^{14}$ Ibid., n. 20-21. CIC-1983, cânones 677-679.

${ }^{15}$ Ibid., n. 23. CIC-1983, cânon 709.

${ }^{16} C I C-1983$, cânon 708 .
} 